\title{
SSRs in Octopus mimus: development and characterization of nine microsatellite loci
}

\author{
SSRs en Octopus mimus: desarrollo y caracterización \\ de nueve loci microsatélites \\ Ricardo Galleguillos ${ }^{1}$, Cristian B. Canales-Aguirre ${ }^{1}$, \\ Sandra Ferrada ${ }^{1}$ and Andrea Barrera ${ }^{1}$
}

\begin{abstract}
${ }^{1}$ Laboratorio de Genética y Acuicultura, Departamento de Oceanografía, Facultad de Ciencias Naturales y Oceanográficas, Universidad de Concepción, Casilla 160-C, Concepción, Chile. cristiancanales@udec.cl

Abstract.- Nine microsatellite loci were developed for Octopus mimus, a cephalopod of commercial importance for artisanal fishermen. Genetic variation at these loci was examined in samples from Clavelito, a Benthic Resources Management Area (AMERB, in Spanish). All nine loci were highly polymorphic, with the number of alleles per locus ranging from 4 to 28 and the expected heterozygosity ranging from 0.651 to 0.946 . These markers will be useful to address issues of population genetics, ecology, conservation and fisheries management related to that species.
\end{abstract}

Key words: Population genetics, AMERBs, cephalopod

\section{INTRODUCTION}

To evaluate how genetic variability is distributed it is necessary to use polymorphic molecular markers. In the last few years, microsatellites have been some of the most used molecular markers for determining genetic variability and genetic structure levels (Barbará et al. 2008). These codominant markers are higly polimorphic, with motifs of 1 to 6 nucleotides in length, organized in tandems, widely distributed along the genome (Tautz 1989).

In cephalopods as in other marine groups, few studies have been devoted to identify and characterize polymorphic microsatellite loci. This is unusual, due to the low genetic diversity that has been observed using others molecular markers in cephalopods (i.e., Allozymes: Brierley et al. 1995, Triantafillos et al. 2004 and mitochondrial DNA: Oosthuizen et al. 2004).

Octopus mimus (Gould, 1852), is a member of Octopodidae Family, it inhabits rocky shore systems in the Southeast Pacific from northern Perú to central Chile. Biological traits such as separate sexes, internal fertilization and a semelparous reproductive strategy (Leite et al. 2008) make this species a good model to answer questions about genetic connectivity. Most studies in the Genus Octopus have focused on determining the phylogeny (e.g., Warnke 2004) and only a few focus on their population biology. Even a smaller number of these studies used microsatellite loci as a tool for determining genetic structure (e.g.,
Greatorex et al. 2000, Cabranes et al. 2008, Doubleday et al. 2009). Up until now, there is no information about $O$. mimus population genetics. In this paper, we describe the isolation, characterization and utility of nine microsatellite loci for $O$. mimus in one Chilean resource management area.

\section{Materials AND Methods}

High molecular weight DNA was extracted from arm tissue of 20 individuals from both sexes using a salting-out protocol (Jowett 1986). The genomic library was developed by Genetic Identification Services ${ }^{1}$. Briefly, the DNA was partially digested with a cocktail of seven blunt-end restriction enzymes (HaeIII, StuI, EcoRV, ScaI, BsrBI, $P v u \mathrm{II}, \mathrm{HiuCII})$. Fragments between 350 and $700 \mathrm{bp}$ were selected by gel extraction and ligated to a $20 \mathrm{bp}$ oligonucleotide adaptor containing a Hind III restriction site at the 5 ' end. Microsatellite enrichment was achieved using streptavidin-coated magnetic beads and 5'-biotinylated $\mathrm{CA}_{15}, \mathrm{AAC}_{12}, \mathrm{TACA}_{8}$ and $\mathrm{TAGA}_{8}$ oligonucleotide probes. The captured molecules were amplified by PCR using a primer complementary to the adaptor, digested with HindIII to remove the adaptor, and ligated into the HindIII site of the pUC19 vector. The plasmids were then electroporated into Escherichia coli DH5. Recombinant clones, identified by blue-white

${ }^{1}$ Genetic Identification Services, Chatsworth. <http://www.genetic-id-services.com> 
selection, were chosen arbitrarily for sequencing on an ABI 377 using the Big Dye Terminator Cycle Sequencing methodology (Applied Biosystems). Specific primers flanking the identified microsatellite sequences were designed using Designer PCR version 1.03 (Research Genetics) (Table 1). The microsatellite loci were amplified in $10 \mu 1$ reactions containing $1 \mathrm{X}$ PCR buffer, $2 \mathrm{mM} \mathrm{MgCl}_{2}$, $0.2 \mathrm{mM}$ forward primer (fluorescently labeled), $0.2 \mathrm{mM}$

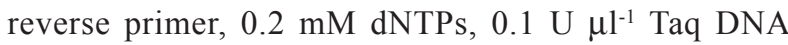
polymerase (Invitrogen), and $20 \mathrm{ng}$ of genomic DNA template. PCR was performed in a PTC-200 (MJ Research) thermal cycler with the following parameters: $94^{\circ} \mathrm{C}$ for 3 min, followed by 34 cycles of $94^{\circ} \mathrm{C}$ for $40 \mathrm{~s}, 56^{\circ} \mathrm{C}$ for $40 \mathrm{~s}$, $72^{\circ} \mathrm{C}$ for $30 \mathrm{~s}$, and a final extension at $72^{\circ} \mathrm{C}$ for $4 \mathrm{~min}$. All loci successfully amplified under the same conditions. The PCR products were analyzed on an ABI 3330 DNA sequencer. Alleles were scored using Peak Scanner v1.0, with GS500 (Applied Biosystems) as the internal size standard.

To characterize the polymorphism of each locus we used 100 individuals from Clavelito, Chile. To evaluate the potential presence of null alleles and genotyping artifacts (stutter bands or large dropout alleles) we first checked the data set with MICRO-CHEKER v2.2.3 software (Van Oosterhout et al. 2004). The number of alleles $(\mathrm{Na})$, the expected $(\mathrm{He})$ and observed (Ho) levels of heterozygosity were obtained using GENALEX v6 (Peakall \& Smouse 2006). Deviations from Hardy-Weinberg equilibrium $(\mathrm{H} \& \mathrm{~W})$ and gametic disequilibrium between markers were tested using ARLEQUIN v3.1 (Excoffier $e t$ al. 2005). All probability values were estimated using 10000 permutations.

\section{RESUltS AND DISCUSSION}

We observed a significant departure from HWE in four loci (i.e., OmimA2, OmimB111, OmimC1 and OmimC122). None of the studied loci showed gametic disequilibrium. On the other hand, the results did not show any score errors like large allelle dropout and stutter bands. Two loci showed heterozygotes deficiency: OmimA105 and OmimB111 (Table 1) which, in this case, could be attributed mainly to: a) admixture of individuals captured over a large geographical area that may include more than one panmictic unit (Wahlund effect), b) null alleles, as some of the sequences (allele) could not be amplified, the number of heterozygotes is sub estimated, c) imbreeding

Table 1. Characteristics of the microsatellite loci isolated for the Octopus mimus. The values reported for each marker are the allele size range (bp), the number of alleles $(\mathrm{Na})$, the observed $(\mathrm{Ho})$ and the expected $(\mathrm{He})$ heterozygosity, and the GenBank accession number. Omim: Octopus mimus. *: $P<0.05 ;{ }^{* *}: P<0.01 /$ Características de los loci microsatélites aislados en Octopus mimus. Los valores reportados para cada marcador son el rango del tamaño alélico $(\mathrm{pb})$, el número de alelos $(\mathrm{Na})$, la heterocigosidad observada (Ho) y esperada (He), y el número de acceso a GenBank. Omim: Octopus mimus. *: $P<0,05 ;{ }^{* *}: P<0,01$

\begin{tabular}{|c|c|c|c|c|c|c|c|}
\hline \multirow[t]{2}{*}{ Locus } & \multirow[t]{2}{*}{$\mathrm{N}^{\circ}$ Genbank } & \multirow[t]{2}{*}{ Primer sequence $\left(5^{\prime}-3^{\prime}\right)$} & \multirow[t]{2}{*}{ Repeat unit } & \multirow{2}{*}{$\begin{array}{l}\text { Size range } \\
\quad(b p)\end{array}$} & \multicolumn{3}{|c|}{ Clavelito } \\
\hline & & & & & $\mathrm{Na}$ & Ho & $\mathrm{He}$ \\
\hline $\operatorname{Omim} \mathrm{A} 2$ & GU584076 & $\begin{array}{l}\text { F: TCAATGGATGTTGATGTCAGA G } \\
\text { R: TTCCAGGCAAGGTAATATCTTG }\end{array}$ & $(\mathrm{AT})_{4}(\mathrm{GT})_{3} \mathrm{~N}_{2}(\mathrm{GT})_{6} \mathrm{~N}_{4}(\mathrm{GT})_{3} \mathrm{~N}_{7}(\mathrm{AT})_{5} \mathrm{~N}_{2}(\mathrm{GT})_{14}$ & 268-306 & 8 & 0.893 & $0.816^{*}$ \\
\hline OmimA103 & GU584077 & $\begin{array}{l}\text { F: CATTGCTGAACGAAGAACTC } \\
\text { R: GCTTATCCCGAACAGGTAAT }\end{array}$ & $(\mathrm{ATCT})_{6}$ & $218-350$ & 28 & 1 & 0.939 \\
\hline OmimA104 & GU584078 & $\begin{array}{l}\text { F: TGGTTGATAGAAACTGTGTCG } \\
\text { R: GTTGTGGTGATGGTGACTG }\end{array}$ & $(\mathrm{CCA})_{6} \mathrm{~N}_{3}(\mathrm{CCA})_{2}$ & 186-276 & 13 & 0.936 & 0.880 \\
\hline OmimA105 & GU584079 & $\begin{array}{l}\text { F: GCCCTTTTGTTGTAATAATACG } \\
\text { R: TTCTCGCTAATGGCAGTTC }\end{array}$ & $(\mathrm{AC})_{28}$ & $194-270$ & 24 & 0.850 & 0.946 \\
\hline OmimB101 & GU584080 & $\begin{array}{l}\text { F: CACCAAGTCACAGACATCTTG } \\
\text { R: GCCAGATAAACAACAATAGCTG }\end{array}$ & $(\mathrm{CA})_{54}$ & 206-256 & 4 & 0.467 & 0.651 \\
\hline OmimB111 & GU584081 & $\begin{array}{l}\text { F: TCCTGATTCAGTCATTTACAGG } \\
\text { R: GGGTTCTGTTTCTTTGACATG }\end{array}$ & $(\mathrm{GT})_{5}(\mathrm{GA})_{15}$ & $186-300$ & 8 & 0.273 & $0.826^{* *}$ \\
\hline Omim $\mathrm{C} 1$ & GU584082 & $\begin{array}{l}\text { F: CGTGTGTCAACCAATTTC } \\
\text { R: GGTGTAGTTAAATGGCATACTC }\end{array}$ & $(\text { ATGT })_{13}(\mathrm{GT})_{12} \mathrm{~N}_{2}(\mathrm{GT})_{5} \mathrm{~N}_{2}(\mathrm{GT})$ & $133-213$ & 14 & 0.938 & $0.805^{* *}$ \\
\hline Omim $\mathrm{C} 106$ & GU584083 & $\begin{array}{l}\text { F: TGCCATCAAAGTGACACTG } \\
\text { R: AACCACAGATACTCGAAGAATG }\end{array}$ & $(\text { TGTA })_{20} \mathrm{~N}_{4}(\mathrm{TGTA})_{9}$ & $188-300$ & 10 & 0.862 & 0.747 \\
\hline Omim $\mathrm{C} 122$ & GU584084 & $\begin{array}{l}\text { F: ATTGTTGAAATCGCAACTGT } \\
\text { R: AATTCTCATAATCGCTGTTGTG }\end{array}$ & $(\mathrm{ACT})_{19}$ & $118-256$ & 17 & 0.942 & $0.800^{* *}$ \\
\hline
\end{tabular}


and d) selection. According to our results, null alleles are the most plausible cause of heterozygotes deficiency at these two loci, as suggested by the excess of homozygotes obtained by the Micro-Checker software. Heterozygosity deficits due to null alleles have been recorded in Octopus species, (e.g., O. vulgaris, Casu et al. 2002, Cabranes et al. 2008, O. maorum, Doubleday et al. 2008, O. maya, Juárez et al. 2010). The presence of heterozygosity deficit could support the low variability recorded in other molecular markers used in cephalopods (Allozyme, Maltagliati et al. 2002; mitochondrial DNA, Oosthuizen et al. 2004). Moreover, life history traits like semelparity, low fecundity and territorial behavior could promote inbreeding and consequently the heterozygosity deficit.

The Na per locus ranged from 4 to 28 , the Ho from 0.273 to 1 and the He varied from 0.651 to 0.946 (Table 1). Polymorphism found in microsatellite loci of $O$. mimus is comparable with other studies in other members of the genus Octopus. $\mathrm{He}$ in O. mimus (mean $\mathrm{He}=0.823$ ) was less than $\mathrm{He}$ in $O$. vulgaris (mean $\mathrm{He}=0.874$, Cabranes et al. 2008; mean $\mathrm{He}=0.91$, Murphy et al. 2002) and $O$. maorum (mean $\mathrm{He}=0.85$, Doubleday et al. 2008). On the other hand, average $\mathrm{He}$ in $O$. mimus was greater than $\mathrm{He}$ in O. maya (mean 0.645, Juárez et al. 2010) and O. vulgaris (mean $\mathrm{He}=0.765$, Greatorex et al. 2000).

In summary, this work provides a significant genetic tool for future population genetic studies, which should improve government management policies to maintain the sustainability of these important fisheries, and helping not only to promote the conservation of the fishing stock, but also to conserve genetic diversity of this cephalopod along the Chilean coast.

\section{ACKNOWLEDGMENT}

Sandra Ferrada and Cristian B. Canales-Aguirre were supported by Doctoral Fellowships for the 'Programa de Doctorado en Sistemática y Biodiversidad', from the graduate school of the Universidad de Concepción. Sandra Ferrada was supported by a CONICYT doctoral fellowship. This work forms part of the FIP 2008-39 Project.

\section{LITERATURE CITED}

Barbará T, C Palma-Silva, GM Paggi, F Bered, MF Fay \& C Lexer. 2007. Cross-species transfer of nuclear microsatellite markers: potential and limitations. Molecular Ecology 16: 3759-3767.
Brierley AS, JP Thorpe, GJ Pierce, MR Clarke \& PR Boyle. 1995. Genetic variation in the neritic squid Loligo forbesi (Myopsida: Loliginidae) in the northeast Atlantic Ocean. Marine Biology 122: 79-86.

Cabranes C, P Fernandez-Rueda \& JL Martínez. 2008. Genetic structure of Octopus vulgaris around the Iberian Peninsula and Canary Islands as indicated by microsatellite DNA variation. ICES Journal of Marine Science 65: 12-16.

Casu M, F Maltagliati, M Meloni, D Casu, P Cossu, G Binelli, M Curini-Galletti \& A Castelli. 2002. Genetic structure of Octopus vulgaris (Mollusca, Cephalopoda) from the Mediterranean Sea as revealed by a microsatellite locus. Italian Journal of Zoology 69: 295-300.

Doubleday ZA, GT Pecl, JM Semmens \& LV Danyushevsky. 2008. Using stylet elemental signatures to determine the population structure of Octopus maorum. Marine Ecology Progress Series 360: 125-133.

Doubleday ZA, JM Semmens, AJ Smolenski \& PW Shaw. 2009. Microsatellite DNA markers and morphometrics reveal a complex population structure in a merobenthic octopus species (Octopus maorum) in south-east Australia and New Zealand. Marine Biology 156: 1183-1192.

Excoffier L, G Laval \& S Schneider. 2005. Arlequin 3.01: An integrated software package for population genetics data analysis. Evolutionary Bioinformatics Online 1: 47-50.

Greatorex E, C Jones, J Murphy, L Key, A Emery \& P Boyle. 2000. Microsatellite markers for investigating population structure in Octopus vulgaris (Mollusca: Cephalopoda). Molecular Ecology 9: 641-642.

Jowett T. 1986. Preparation of nucleic acids. In: Roberts DB (ed). Drosophila: A practical approach, pp. 275-286. IRL Press, Oxford.

Juárez OE, C Rosas \& L Arena. 2010. Heterologous microsatellites reveal moderate genetic structure in the Octopus maya population. Fisheries Research 106: 209213.

Leite T, M Haimovic, W Molina \& K Warnke. 2008. Morphological and genetic description of Octopus insularis, a new cryptic species in the Octopus vulgaris complex (Cephalopoda: Octopodidae) from tropical southwestern Atlantic. Journal of Molluscan Studies 74: 63-74.

Maltagliati F, P Belcari, D Casu, M Casu, P Sator, G Vargiu \& A Castelli. 2002. Allozyme genetic variability and gene Xow in Octopus vulgaris (Cephalopoda, Octopodidae) from the Mediterranean Sea. Bulletin of Marine Sciences 71: 437-486.

Murphy JM, E Baguerias, LN Key \& PR Boyle. 2002. Microsatellite DNA markers discriminate between two Octopus vulgaris (Cephalopoda: Octopoda) fisheries along the northwest African coast. Bulletin of Marine Science 71: 545-553. 
Oosthuizen A, M Jiwaji \& P Shaw. 2004. Genetic analysis of the Octopus vulgaris population on the coast of South Africa. South African Journal of Science 100: 603-607.

Peakall R \& PE Smouse. 2006. GENALEX 6: genetic analysis in Excel. Population software for teaching and research. Molecular Ecology Notes 6: 288-295.

Tautz D. 1989. Hypervariability of simple sequences as a general source of polymorphic DNA markers. Nucleic Acids Research 17: 6463-6471.

Triantafillos L, GD Jackson, M Adams \& BL McGrathSteer. 2004. An allozyme investigation of the stock structure of arrow squid Nototodarus gouldi (Cephalopoda: Ommastrephidae) from Australia. ICES Journal of Marine Science 61: 829-835.
Van Oosterhout C, WF Hutchinson, DPM Wills \& P Shipley. 2004. MICRO-CHECKER: software for identifying and correcting genotyping errors in microsatellite data. Molecular Ecology Notes 4: 535-538.

Warnke K, R Söller, D Blohm \& U Saint-Paul. 2004. A new look at geographic and phylogenetic relationships within the species group surrounding Octopus vulgaris (Mollusca, Cephalopoda): indications of very wide distribution from mitochondrial DNA sequences. Journal of Zoological Systematics and Evolutionary Research 42: 306-312.

Received 12 February 2011 and accepted 6 October 2011 